NBER WORKING PAPER SERIES

\title{
THE EFFECTS OF WEBSITE PROVISION ON THE DEMAND FOR GERMAN WOMEN'S MAGAZINES
}

\author{
Ulrich Kaiser \\ Working Paper 8806 \\ http://www.nber.org/papers/w8806 \\ NATIONAL BUREAU OF ECONOMIC RESEARCH \\ 1050 Massachusetts Avenue \\ Cambridge, MA 02138 \\ February 2002
}

I wish to thank Christine Konrad and Laura Berndt of Gruner + Jahr, Carmen Basler of Burda Advertsing Center, Linda Knab of Arbeitsgemeinschaft Markt-Analyse and Birgit Zöllner of Jahreszeitenverlag for kind data provision and advice. I also gratefully acknowledge the perfect data support provided by Marco Kramer. This research benefited from comments received at workshop presentation at Harvard University and the NBER, in particular from Ernst R. Berndt, Iain Cockburn, Liran Einav, Markus Möbius, Maria Moral, Julie Mortimer, Ariel Pakes and Minjae Song. It also gained from kitchen-conversations with Richard B. Freeman on the premises of the NBER. I am indebted to the VolkswagenStiftung for funding this research within the 'Empirical Economics -- Program of Fellowships for German Researchers in the United States' program and to the NBER, especially Ernst R. Berndt, for hosting me during the academic year 2001/2002. The views expressed herein are those of the author and not necessarily those of the National Bureau of Economic Research.

(C) 2002 by Ulrich Kaiser. All rights reserved. Short sections of text, not to exceed two paragraphs, may be quoted without explicit permission provided that full credit, including (C) notice, is given to the source. 
The Effects of Website Provision on the Demand for German Women's Magazines Ulrich Kaiser

NBER Working Paper No. 8806

February 2002

JEL No. C3, L1

\begin{abstract}
The effect of website provision on the demand for German women's magazines is analyzed using differentiated product demand models estimated on panel data that cover the period 1990-2000. Descriptive evidence on the magazines' website contents suggests that websites are used to provide supplementary information and to advertise the current print issue. Website provision does not significantly affect magazines' market shares. This result is robust with respect to the application of alternative econometric approaches to identify the demand model. A counter-factual analysis shows, however, that online magazines would loose around 0.3 per cent in market shares if they went back offline. Likewise, magazines that are currently offline may gain market shares of between 0.07 and 0.37 per cent if they launched a website. Interestingly, some of the potential 'winners' from going online actually launched a website in 2001.
\end{abstract}

\author{
Ulrich Kaiser \\ Harvard University \\ Department of Economics \\ Littauer, Room 200 \\ Cambridge, MA 02138, \\ NBER, \\ and Centre for European Economic Research \\ Tel: $617-588-1420$ \\ Fax: 617-868-5023 \\ Email: ukaiser@fas.harvard.edu
}




\section{Introduction}

Launching a website is a costly venture. Even if a website already is online, it has to be technically maintained, its contents have to be updated and every now and then a relaunch is in order. At least potentially, additional indirect costs may arise if magazines go online since one might fear that consumers substitute away from the print media towards calling up information from the internet. Given these facts and fears, two questions arise. The first is "why do magazines go online?", followed by "what happens to demand if a magazine goes online?"

This paper aims at answering these questions by looking at the German women's magazine market between 1990 and 2000 using publicly available panel data. The first German women's magazine went online in spring 1996. Two competing magazines followed the same year. By 2000, eight women's magazines out of a total of 41 magazines active in the market provide their own website. This indicates that there are in fact incentives to invest in a website.

In this study, the German women's magazine market and women's magazine websites are descriptively analyzed. Demand effects of website launching are studied using econonometric panel data techniques within a differentiated product demand framework.

An analysis of the characteristics of purchasers of women's magazine shows that consumers purchasing a magazine that went online are more likely to have internet access. Purchasers of magazines that provide a website also use the internet more often at work and at home than purchasers of magazines that are offline. These descriptive results suggest that the decision to launch a website is likely to be to a large extent driven by the readership of the magazine.

An analysis of the ten existing women's magazine websites shows that the content of the websites is complementary to the information provided by the printed magazine. Article downloads are not provided by the magazine websites. Instead, visitors call up a variety of information coming under headings such as 'Beauty and fashion', 'Love and partnership' and 'Today's horoscope'. Important other ingredients of the websites are the table of contents of the most current printed magazine edition, a subscription possibility and links to products of the affiliated publishing group.

Due to the fact that the websites have quite different contents compared to the printed magazines and tend to be used to advertise the current print edition, the possibility to substitute away from the magazine is very limited. Instead, the 
provision of an own website appears to serve as a quality characteristic of the magazine and as a quality signal to consumers. Therefore, the analysis of the effect of website provision on the demand for the print magazine uses a differentiated product demands framework, treating website provision as a magazine quality characteristic.

An identification problem arises from the simultaneous determination of prices and market shares in these demand models. This paper applies two different approaches to identify the parameters of the demand model: (i) traditional instrumental-variable techniques and (ii) estimation of panel data models with autoregressive error terms. The main result of this paper is that website provision does not have a significant effect on market shares. Like most other results, this finding is robust to all of the econometric specifications being considered.

The quantitative effects of website provision are, however, quite sizeable in some cases. A counter-factual analysis that estimates the demand effects of going back offline (for magazines that run a website) and of launching a website (for magazines that are offline) shows that magazines that are online would loose around 0.3 per cent of market shares if it went back offline. Magazines that are offline are estimated to gain between 0.07 and 0.37 per cent if they launch a website. The gain in website launching is largest for magazines targeting women aged between 20 and 29. It is lowest for magazines focussing on women above 70 years of age. The fact that two of the magazines that would belong to the winners from

going online actually launched a website in 2001 provides additional faith in the estimation results.

\section{Descriptive analysis}

\subsection{Why study the women's magazine market?}

There are at least two good arguments for analyzing the women's magazine market: first, it is a large market and second, it is a market in which the actors face fierce competition. These two facts are shown in Table 1. The table is based on a publication entitled 'Markt- und Medienentwicklung 1990-2001' (Gruner + Jahr 2001), edited by one of the large German publishing houses. This data source is described in greater detail in Section 3. Table 1 displays the number of titles, the market shares - measured in terms of copies sold - and the 
Hirshman-Herfindahl index of market concentration for each segment of the German magazine market. ${ }^{1}$ TV magazines and women's magazines own the largest shares of the German magazine market, followed by TV supplements ${ }^{2}$ as well as by car and motor cycle magazines. While TV and women's magazines are almost equal important in terms of market shares, they differ markedly with respect to market concentration and the number of titles published. Market concentration is by far the lowest and the number of published titles is by far the highest in the women's magazine market compared to any other segment in the industry, further motivating the analysis of this particular market segment.

This subsection uses the broad definition of women's magazines as applied by the publishing industry (e.g. Gruner + Jahr 2001). The descriptive and econometric analysis ignores, however, magazines targeting at women aged below 19 years ('Bravo Girl', 'Brigitte Young Miss', 'JOY', 'Mädchen' and 'YoYo') and magazines focussing very narrowly on needlework and handicraft issues ('Burda Mode+Magazin', 'Anna', 'Neue Mode', 'Strick +Schick' and 'Verena') since these two magazine groups operate in a distinctively different submarket than all other magazines considered in this paper, an issue that has been brought to me by industry people. The two magazine groups account for a joint share in the total women's magazine market of 3.9 per cent in 2000 .

\subsection{What types of magazines launch a website?}

Two driving forces may basically be at work when a magazine decides upon launching a website. First, the publishing house might have an interest to signal to consumers and advertising clients that it is up-to-date and at the edge of the technological development. It might also be interested in implementing a joint internet platform for all its magazines to realize returns to scale. Second, consumers might demand to have the opportunity to call up additional information on the internet.

Table 2 displays the names of the magazines that went online, their publishing houses, the total number of titles published by the publishing house, the

\footnotetext{
${ }^{1}$ The definition of the segments follows the Gruner + Jahr (2001) publication mentioned above.

${ }^{2}$ These are weekly supplements to newspapers that cannot be purchased independently of a newspaper.
} 
Table 1: Number of titles, market shares and Hirshman-Herfindahl index for the segments of the German magazine market

\begin{tabular}{lccc}
\hline & & Market & Herfindahl \\
& \# of titles & share & index \\
\hline TV magazines & 16 & 19.4 & 0.0835 \\
Women's magazines & 43 & 19.3 & 0.0377 \\
TV supplements & 4 & 16.2 & 0.3368 \\
Car and motor cycle magazines & 11 & 16.1 & 0.6919 \\
News magazines & 13 & 9.1 & 0.1343 \\
Living and gardening magazines & 8 & 4.0 & 0.2934 \\
Computer, photo and video magazines & 7 & 3.0 & 0.1954 \\
Teenager magazines & 5 & 1.8 & 0.3 \\
Science, nature and culture magazines & 7 & 1.8 & 0.2023 \\
Business and economics magazines & 8 & 1.7 & 0.1315 \\
Life-, City- and Men's magazines & 6 & 1.6 & 0.1704 \\
Fiction magazines & 4 & 1.4 & 0.7652 \\
Food magazines & 5 & 1.1 & 0.2718 \\
Sports magazines & 7 & 1.1 & 0.3917 \\
Erotic magazines & 4 & 0.9 & 0.2923 \\
Parenthood magazines & 4 & 0.9 & 0.3254 \\
Do-it-yourself magazines & 2 & 0.2 & 0.5412 \\
Health magazines & 2 & 0.2 & 0.5954 \\
\hline
\end{tabular}

Note: Market share is measured by the total number of copies sold in each segment over the total number of copies sold in the entire market. The Hirshman-Herfindahl index is calculated as the sum of the squared market shares of each title in each segment. Source: Gruner + Jahr (2001).

number of women's magazines published by the publishing house and the magazines' internet addresses. ${ }^{3}$ Magazines and publishers are matched on the basis on information called up on the internet at http://medialine.focus.de/ and http://www.media-daten.de/. Both sources provide a brief description of the magazines, including the publishers names. With the exception of the small publishing houses Milchstrasse and Condé Nast, all other publishers also edit women's magazines that have not yet gone online. Even if magazines have the same publisher, such as 'Elle' and 'Freundin' (both Burda Media), their websites appear to be quite dissimilar with respect to website organization and design, suggesting

\footnotetext{
${ }^{3}$ This data is gathered from personal inquiries by telephone or email as well as from information provided on the magazines' and publishers' websites.
} 
Table 2: Magazines that went online and their publishing houses

\begin{tabular}{|c|c|c|c|c|c|}
\hline Magazine & Publisher & $\begin{array}{c}\text { Publisher's } \\
\text { total } \\
\text { \# of titles }\end{array}$ & $\begin{array}{c}\text { \# of } \\
\text { publisher's } \\
\text { women } \\
\text { titles }\end{array}$ & $\begin{array}{c}\text { First } \\
\text { year } \\
\text { online }\end{array}$ & $\begin{array}{c}\text { Inter- } \\
\text { net } \\
\text { address }\end{array}$ \\
\hline Allegra & Axel Springer & 20 & 3 & 1996 & www.allegra.de \\
\hline Amica & Milchstrae & 7 & 1 & 1997 & www.amica.de \\
\hline Brigitte & Gruner + Jahr & 28 & 4 & 1997 & www.brigitte.de \\
\hline Cosmopolitan & MVG & 3 & 2 & 1998 & www.cosmopolitan.de \\
\hline Elle & Burda & 20 & 9 & 1996 & www.elle.de \\
\hline Freundin & Burda & 20 & 9 & 1996 & www.freundin.de \\
\hline Petra & Jahreszeiten & 15 & 3 & 2000 & www.petra.de \\
\hline Vogue & Condé Nast & 3 & 1 & 1999 & www.vogue.de \\
\hline
\end{tabular}

Note: The data refers to 2000. Source: Telephone and email inquiries; publishers' and magazines' website information.

that publishing houses do not aim at providing lookalike websites based on a joint platform for their magazines. The decision to launch a website hence appears not mainly be driven by the publishing house. Interestingly in this respect, the decision to relaunch a website also seems to be unrelated to publisher affiliation since the three magazines that ever relaunched their website - Allegra, Brigitte and Cosmopolitan (all relaunched in 2000) - belong to different publishing houses. Indeed, the magazines that went online are much more similar with regard to internet use of their readership than with respect to their publishers, as Table 3 suggests. Table 3 is based on data that was made available to me by Burda Advertsing Center ${ }^{4}$ and compares the extent of internet use between magazines that went online and magazines that did not provide a website in 2000. Table 3 shows, by displaying means and medians of the consumer internet use characteristics as well as by testing for significant difference in means ( $t$-test with unequal variances ) and medians (ranksum test), that purchasers of magazines that went online use the internet more often than purchasers of magazines that are still offline. The mean share of internet users of purchasers of magazines that are

\footnotetext{
${ }^{4}$ This data is based on a consumer survey collected by the 'Institut für Demoskopie, Allensbach', Germany, in spring 2000. 20,606 realized interviews were conducted. For more information on this data, see http://www.awa-online.de/. The Burda Advertsing data is the only data set used in this paper that is not publicly available.
} 
Table 3: Differences in internet access and internet use between purchasers of magazines with and without websites

\begin{tabular}{lcccccc}
\hline & & & & & & Ranksum \\
& W/ website & \multicolumn{2}{c}{ W/o website } & $t$-test & test \\
& Mean & Median & Mean & Median & $p$-value & $p$-value \\
\hline General internet use & 26.7 & 26.8 & 11.2 & 10.3 & 0.0002 & 0.0001 \\
Internet used in private & 22.0 & 23.2 & 9.4 & 8.8 & 0.0001 & 0.0001 \\
Internet used in office & 11.5 & 10.9 & 4.7 & 4.4 & 0.0000 & 0.0001 \\
Internet access from home & 17.8 & 18.5 & 7.1 & 6.3 & 0.0002 & 0.0001 \\
Internet access from office & 8.3 & 7.4 & 3.1 & 2.7 & 0.0001 & 0.0001 \\
\hline
\end{tabular}

online is 26.7 per cent which is to compare with a mean share of internet users of 11.2 per cent for purchasers of magazines that are offline. These differences also show up if it is further differentiated with respect to internet access/internet use at home and/or at work. They also hold if internet use and internet access is compared within magazine segments, e.g. within magazines groups that focus on consumers of similar.

\subsection{Key contents of the magazine's websites}

In contrast to many newspapers that basically put up the entire set of articles contained in the current printed issue on the internet, the websites of the women's magazines do not provide information identical to those offered by the print media. They merely provide an additional and complementary resource of news and recommendations.

A visit of the ten websites in early October 2001 and a revisit in early February 2002 indeed suggest that there is very little overlap between the printed magazine and the website information. Neither are full text downloads of articles available nor do the topics covered by the website coincide with the contents of the current magazine edition. All of the websites offer, however, online subscription possibilities, links to other magazines marketed by the own publishing group and a table of contents of the most current magazine issue. Self-advertisement hence appears to play an important role in the decision to launch a website. Instead of placing full text articles online, the magazine websites contain information 
that might be termed 'timeless', meaning that they allow to gather information that is not subject to very recent developments. Topics include recommendations concerning furnishing, cooking, nutrition, travelling etc. Two separate website headings also fitting in the 'timeless' category are 'Beauty and fashion', a title that is self-explanatory, as well as 'Love and partnership', which usually contains flirting and sex tips as well as recommendations for a durable partnership. Another feature that is common to all of the eight websites is the provision of an up-to-date horoscope. Other popular website headings include:

Games of chances: website visitors are invited to take part in an online gamble.

Job \& career: provides job hunting recommendations, general career perspectives discussions and in some cases even an online job market.

Chat: a possibility to chat, send e-postcards, subscribe to newsletter etc. is offered here.

Shopping: shopping recommendations are provided here; in one case www.brigitte.de - products can be ordered online.

Table 4 displays the URLs of the eight websites under consideration and shows which magazines provide the respective information.

Another potential reason to launch website is to raise additional money from banner and pop-up advertising. The magazines, however, very sparingly use banner-ads, not exceeding more than two banner ads per page and of sizes below $2 \times 2$ inches. They also do not place pop-up ads.

To summarize, the ten women's magazines that have launched a website are apparently aiming at the following (i) advertise the own print edition as well as other products offered by the publishing house and (ii) provide information complementary to the print magazine. It is also probably fair to say that another, somewhat hidden, reason to launch a website is to signal the current and potential readership that the magazine is 'modern'. This argument is supported by the fact that the magazines that went online advertise their websites on prominent places such as the title page or the table of contents. With regard to the complementary information provision argument and the signalling effect, it hence appears to be reasonable to treat the existence of a website as a quality component in the empirical analysis hereafter.

$[\mathrm{t}]$ 
Table 4: Key information pieces contained in magazine websites

\begin{tabular}{lccccc}
\hline & $\begin{array}{c}\text { Games } \\
\text { of } \\
\text { chances }\end{array}$ & $\begin{array}{c}\text { Job } \\
\text { and } \\
\text { career }\end{array}$ & Chat etc. & $\begin{array}{c}\text { Sanner } \\
\text { ads }\end{array}$ & $\begin{array}{c}\text { Shopping } \\
\text { recommen- } \\
\text { dations }\end{array}$ \\
\hline Allegra & $\mathrm{x}$ & $\mathrm{x}$ & $\mathrm{x}$ & $\mathrm{x}$ & $\mathrm{x}$ \\
Amica & $\mathrm{x}$ & $\mathrm{x}$ & $\mathrm{x}$ & $\mathrm{x}$ & $\mathrm{x}$ \\
Brigitte & & $\mathrm{x}$ & $\mathrm{x}$ & & $\mathrm{x}$ \\
Cosmopolitan & & $\mathrm{x}$ & & & \\
Elle & & $\mathrm{x}$ & $\mathrm{x}$ & $\mathrm{x}$ & $\mathrm{x}$ \\
Freundin & $\mathrm{x}$ & $\mathrm{x}$ & & $\mathrm{x}$ & \\
$\begin{array}{l}\text { Petra } \\
\text { Vogue }\end{array}$ & $\mathrm{x}$ & $\mathrm{x}$ & & $\mathrm{x}$ & \\
\hline
\end{tabular}

Note: Information obtained from website visits in early October 2001. An ' $\mathrm{x}$ ' indicates that the website comes with respective feature.

\section{$2.4 \quad$ Prices and market shares}

Table 5 casts a first spotlight on the women's magazine market by displaying magazines' most current cover prices, least current cover prices, most current market shares (in 2000 or in exit year), least current market shares (in 1990 or in entry year), subscription shares (the number of subscribers over the total number of copies sold; in 2000 or in exit year), year of the first issue and most important consumer age group. It also contains information on the grouping of the respective magazine, a point to that I shall return to below.

Cover prices vary considerably across magazines in 2000 (and of course also in previous years), ranging from a minimum of one DM to a maximum of $11 \mathrm{DM}$ with a mean of 3.5 DM and a median of 2.5 DM. The modulus which includes 20 per cent of all titles, is $2.5 \mathrm{DM}$ and has moved up by $0.5 \mathrm{DM}$ since 1990. Mean and median prices have also increased. These aggregate price increases are mostly due to price changes in the low price segments while, by contrast, prices of the magazines above or equal to $4 \mathrm{DM}$ have remained remarkably stable in the ten years period.

While at least some changes occurred in the distribution of cover prices between 1990 and 2000, the distribution of market shares has remained fairly stable. Mean and median market shares slightly increased, causing a drop in the HirshmanHerfindahl index of market concentration by -0.0091 . 
Table 5: Key characteristics of the magazines under consideration

\begin{tabular}{|c|c|c|c|c|c|}
\hline & $\begin{array}{c}\text { Most } \\
\text { current } \\
\text { price }\end{array}$ & $\begin{array}{c}\text { Most } \\
\text { current } \\
\text { market } \\
\text { share } \\
\text { (in \%) }\end{array}$ & $\begin{array}{c}\text { Sub- } \\
\text { scrition } \\
\text { share } \\
\text { in } 2000^{+} \\
(\text {in } \%)\end{array}$ & $\begin{array}{c}\text { First } \\
\text { issue } \\
\text { in }\end{array}$ & Group \\
\hline 7 Tage & 2.5 & 0.6 & 16.5 & 1843 & $70 p$ \\
\hline Allegra & 5 & 1.0 & 6.4 & 1995 & $20-29$ \\
\hline Amica & 6 & 1.6 & 5.0 & 1996 & $20-29$ \\
\hline Bella & 2.4 & 2.0 & 14.3 & 1978 & $30-39$ \\
\hline Bild der Frau & 1.4 & 8.6 & 2.9 & 1983 & $30-39$ \\
\hline Brigitte & 4 & 4.8 & 27.2 & 1957 & $40-49$ \\
\hline Cosmopolitan & 5 & 1.7 & 11.6 & 1980 & $20-29$ \\
\hline Das Goldene Blatt & 2.5 & 1.3 & 20.1 & 1971 & $70 p$ \\
\hline Das Neue & 2.6 & 2.1 & 7.4 & 1983 & $70 \mathrm{p}$ \\
\hline Das Neue Blatt & 2.5 & 5.2 & 7.2 & 1968 & $70 \mathrm{p}$ \\
\hline Die Aktuelle & 2.6 & 2.7 & 4.9 & 1979 & $70 \mathrm{p}$ \\
\hline Die Neue Frau & 1.6 & 1.1 & 0.2 & 1999 & $70 \mathrm{p}$ \\
\hline Echo der Frau & 2.5 & 2.0 & 29.7 & 1973 & $70 \mathrm{p}$ \\
\hline Elle & 7.5 & 1.0 & 11.0 & 1988 & $30-39$ \\
\hline Frau aktuell & 2.5 & 1.7 & 19.6 & 1965 & $70 p$ \\
\hline Frau im Leben & 3.5 & 0.7 & 59.8 & 1948 & $70 \mathrm{p}$ \\
\hline Frau im Spiegel & 2.7 & 3.3 & 6.7 & 1945 & $70 \mathrm{p}$ \\
\hline Frau mit Herz & 2.5 & 0.8 & 17.3 & 1949 & $70 \mathrm{p}$ \\
\hline Freizeit Revue & 2.6 & 5.4 & 19.0 & 1970 & $70 \mathrm{p}$ \\
\hline Freundin & 4 & 3.1 & 12.4 & 1948 & $40-49$ \\
\hline Für Sie & 4 & 3.1 & 21.2 & 1948 & $40-49$ \\
\hline Glücks Revue & 2 & 1.6 & 13.3 & 1986 & $70 p$ \\
\hline Heim und Welt & 2.3 & 0.5 & 3.9 & 1948 & $70 \mathrm{p}$ \\
\hline Journal f. d. Frau & 4 & 2.0 & 15.5 & 1978 & $40-49$ \\
\hline Laura & 1.5 & 2.5 & 1.2 & 1995 & $30-39$ \\
\hline Lea & 1.5 & 1.4 & 0.0 & 1999 & $30-39$ \\
\hline Lisa & 1.5 & 3.1 & 1.5 & 1995 & $30-39$ \\
\hline Mach mal Pause & 2.1 & 1.6 & 19.4 & 1994 & $70 p$ \\
\hline Madame & 11 & 0.5 & 27.5 & 1950 & $40-49$ \\
\hline Marie Claire & 7 & 0.8 & 11.9 & 1990 & $20-29$ \\
\hline Maxi & 7 & 1.4 & 6.0 & 1986 & $20-29$ \\
\hline Mini & 1.4 & 1.5 & 4.0 & 1986 & $30-39$ \\
\hline Neue Post & 2.5 & 6.5 & 9.8 & 1948 & $70 p$ \\
\hline Neue Welt & 2.5 & 2.0 & 12.0 & 1932 & $70 \mathrm{p}$ \\
\hline Neue Woche & 1.5 & 2.5 & 0.3 & 1998 & $70 \mathrm{p}$ \\
\hline Petra & 5 & 1.8 & 7.2 & 1969 & $40-49$ \\
\hline Prima Carina $^{b}$ & 4.5 & 1.3 & 15.6 & 1977 & $20-29$ \\
\hline Ratg. Frau u. Fam. & 3.8 & 1.7 & 75.5 & 1901 & $40-49$ \\
\hline Tina & 2.4 & 5.1 & 19.7 & 1975 & $30-39$ \\
\hline Viel Spass & 1 & 3.6 & 0.0 & 1999 & $70 p$ \\
\hline Vital & 4 & 1.6 & 16.7 & 1966 & $20-29$ \\
\hline Vogue & 11 & 0.6 & 19.0 & 1979 & $20-29$ \\
\hline Mean & 3.6 & 2.3 & 14.3 & 1969 & \\
\hline Median & 2.6 & 1.7 & 11.9 & 1978 & \\
\hline
\end{tabular}

Note: ${ }^{a}$ exit in 1998. The market shares do not necessarily add to 100 since they do not refer to the same date due to market entries and markeg exits. 'Least current market share' and 'Least current price' either refer to 1990 or to the year of the first issue. The grouping variable is explained Subsection 2.6. 'Journal f.d. Frau' is shorthand for 'Journal für die Frau' and 'Ratg. 
The years of the first appearances of the individual titles displayed in Table 5 describe to some extent the history of the German women's magazine market. The years 1948 to 1950 were characterized by a total of eight entries into the market. Entry was comparatively modest in the following years until the early/mid 1980s, when another eight new magazines were published. A third wave of market entry occurred in the late 1990s, when nine women's magazines entered the market between 1994 and 1999. Six of them were low-price magazine costing below 1.5 DM, the other three belong to the high/medium price segment with cover prices between 3.6 and 5 DM.

One exit, that of 'Prima Carina', occurs between 1990 and 2000. The most prominent market withdrawal probably is the German edition of the well-known U.S. fashion magazine 'Harper's Bazaar' which is not listed in the table. ${ }^{5}$ It entered the market in 1987 and exited in 1992, priced 8.5 DM and with a market share of 0.05 per cent, after experiencing a total decrease in sales by 27 per cent.

\subsection{Cover prices and subscription prices}

While consumers can save up to 80 per cent of a magazine's cover price in the U.S. in case of subscription, ${ }^{6}$ saving possibilities rom subscription are very limited in the German women's magazine market. A comparison of cover and subscription prices in early October 2001 shows that for 17 magazines subscription and cover prices are exactly the same. For three magazines, consumers can actually save by subscribing. They can save two DM (or 28.6 per cent) when subscribing to 'Maxi' and 0.50 DM when subscribing to 'Allegra' and 'Marie Claire' (savings of 7.1 and 10 per cent respectively). The other magazines do not offer subscription. The subscription share, calculated as the ratio of the number of copies sold to subscribers and the total number of copies sold, varies considerably across the magazines. The minimum is 0.03 per cent ('Lea'), the maximum is 75.5 per cent ('Ratgeber Frau und Familie') in 2000. Unsurprisingly, older magazines tend to have a larger subscription share than younger magazines.

\footnotetext{
${ }^{5}$ It was impossible for me to obtain information other than price and market share for 'Harper's Bazaar' so that it is left out in the further analysis.

${ }^{6}$ This at least was the case for a subscription to 'U.S. news \& world report', a weekly U.S. news magazine, in early October 2001.
} 


\subsection{Magazine contents}

There is a great variety of topics covered in the women's magazine market. A market fact-book by one of the leading German publishers (Jahreszeitenverlag 2001) distinguishes between the following 15 topics covered by women's magazines: (i) 'beauty' (fashion, cosmetics, hairdressing), (ii) 'cooking, eating and drinking', (iii) 'furnishing, living and gardening', (iv) 'health and fitness', (v) 'marriage, partnership and sexual education', (vi) 'vacation and travelling', (vii) 'advice and law, career and money', (viii) 'computer, internet, telecommunication', (xi) 'politics and economics', (xii) 'science, sociology, nature and technology', (xiii) 'art and cultural events', (xiv) 'VIPs' and (xv) 'fiction, riddles, humor'. Jahreszeitenverlag (2001) also subdivides the German women's magazine market into subgroups. This grouping is, however, essentially based on price and periodicity. Given the fact that such a grouping is not informative in terms of actual magazine contents and hence in terms of sensitive magazine grouping, the Jahreszeitenverlag (2001) grouping does not appear to be very useful for the Nested Logit analysis to be conducted in Section 4.4.

Instead of following the Jahreszeitenverlag (2001) classification, I group the magazines according to their main customer age groups. ${ }^{7}$ Since magazines targeting at the same main age groups provide similar magazine contents, this seems to be a straightforward approach. For example, if a magazine's most important consumer age group are purchasers aged between 20 and 29 years, this magazine is associated with age group 20-29 as displayed in Table 5. In Table 6, some descriptive statistics on the magazine age groups are provided. Magazines that target at consumers aged over 70 years play the most important role in the women's magazine market. They posses the largest market share in terms of the number of titles, circulation share and sales share. The largest advertising share (group advertising sales over total advertising sales) is, however, occupied by magazines targeting 40-49 year old women. Website provision is offered only by magazines targeting the age groups 20-29 and 40-49 years.

\footnotetext{
${ }^{7}$ Information on the consumer age distribution is unavailable for 'Prima Carina' which left the market before 2000. It is thus classified by myself based on content comparisons to the still existing magazines. The content information on the exited magazines was called up at the following URLs: http://medialine.focus.de/, http://www.media-daten.de/ and http://www.netzmarkt.de/.
} 
Table 6: Magazine group characteristics

\begin{tabular}{lccccc}
\hline $\begin{array}{l}\text { Magazine } \\
\text { group }\end{array}$ & $\begin{array}{c}\text { \# of } \\
\text { titles }\end{array}$ & $\begin{array}{c}\text { Circulation } \\
\text { share } \\
\text { (in \%) }\end{array}$ & $\begin{array}{c}\text { Sales } \\
\text { share } \\
\text { (in \%) }\end{array}$ & $\begin{array}{c}\text { Advertising } \\
\text { sales } \\
\text { share (in \%) }\end{array}$ & $\begin{array}{c}\text { \# of } \\
\text { website } \\
\text { provided }\end{array}$ \\
\hline $20-29$ & 7 & 9.1 & 18.9 & 20.5 & 4 \\
$30-39$ & 7 & 25.4 & 15.3 & 19.9 & 0 \\
$40-49$ & 7 & 17.9 & 26.9 & 48.7 & 3 \\
$>70$ & 19 & 47.6 & 38.8 & 11.0 & 0 \\
\hline
\end{tabular}

Source: Burda Advertising Center.

\section{Data}

The main data set used in this paper is based on a publication by Gruner + Jahr (2001). ${ }^{8}$ It provides annual averages of (i) circulation, (ii) cover prices, (iii) advertising prices and (iv) advertising volume for the German magazine market. The data covers the time period 1990-2000.

Gruner + Jahr in turn takes the information concerning circulation from the 'Information Association for the Determination of the Spread of Advertising Media' ('Informationsgemeinschaft zur Feststellung der Verbreitung von Werbeträgern e.V', IVW). IVW ascertains, monitors and publishes circulation and magazine dissemination information.

The other information used in the Gruner + Jahr publication is taken from the 'Association Media Analysis' ('Arbeitsgemeinschaft Media-Analyse', AG.MA), an association of the German advertising industry for the research of mass communication. The purpose of the AG.MA is to gather and supply data for media audience measurement. AG.MA closely cooperates with IVW.

Additional information on the (i) number of subscribers, (ii) publication year date of first magazine issue, (iii) the total number of pages and (iv) the total number of advertising pages was downloaded from http://medialine.focus.de. ${ }^{9}$ This information is based on AG.MA publications as well.

Information on the total number of titles published by the women's magazines' publishing houses was gathered from the publishing houses' websites, by telephone interviews and e-mail inquiries to the publishing houses.

Data on the date of the first website launch was gathered by phone calls and by

\footnotetext{
${ }^{8}$ This publication is publicly available at a nominal fee of DM 100.-.

${ }^{9}$ MediaLine is a costless service provided by the German news magazine 'Focus'.
} 
sending emails to the editorial staff of the magazines.

Appendix A provides an overview of the data resources used in this paper.

\section{Empirical analysis}

\subsection{Empirical framework}

Discrete-choice models of product differentiation (Anderson et al. 1992; Berry 1994) provide a somewhat natural framework for studying the determinants of demand for women's magazines. Internet provision is considered as a quality characteristic, and its effect on magazine demand is analyzed using Logit and Nested Logit models of product differentiation. In contrast to existing studies based on these frameworks (e.g. Moral and Jaumandreu 1998; Trajtenberg 1989; Verboven 1996; Wojcik 2000), I explicitly use the panel dimension of the data to control for unobserved product characteristics.

Logit and Nested Logit models are comparatively simple to implement. The simplicity, however, comes at a cost: both models place restrictive assumptions on own and cross-price elasticities (Berry 1994; Berry et al. 1995), ${ }^{10}$ so that recent research uses the more flexible full random coefficient model to estimate models for differentiated product demands (Berry et al. 1995, 1997; Berry and Pakes 1999; Davis 1998, 2000; Nevo 2000a, 2001; Petrin, 1998). ${ }^{11}$ Given that (i) own and cross-price elasticities are of secondary interest only, (ii) estimating these models usually implies not to explicitly use the panel character of the data $^{12}$ and (iii) estimating a random coefficients model is computationally more burdensome, ${ }^{13}$ Logit and Nested Logit models appear to actually serve very well

\footnotetext{
${ }^{10}$ This is due to the well-known 'Independence of Irrelevant Alternatives' assumption underlying multinomial logit models.

${ }^{11}$ I term it a 'full' random coefficients model since the nested Logit model also is a random coefficients model with random coefficients on the group dummy variables (see below).

${ }^{12}$ For computational reasons, it is recommended to consider different submarkets in random coefficient models instead of considering one single market (Nevo 2000b). If panel data is available, each year is treated as a different market (e.g. Berry et al. 1995; Nevo 2000a, 2001) so that unobserved product heterogeneity cannot be modelled using standard panel data technique such as fixed or random effects estimation.

${ }^{13}$ Introducing random effects causes the market share equations to be no longer analytically solveable, calling for simulation techniques to estimate the model.
} 
for the current purpose.

The general assumption underlying models of product differentiation choice are based on the following functional form of consumer utility,

$$
u_{i j t}=\boldsymbol{x}_{\boldsymbol{j} \boldsymbol{t}} \boldsymbol{\beta}+\alpha p_{j t}+\tau_{t}+\xi_{j t}+\epsilon_{i j t}
$$

where $u_{i j t}$ denotes the utility of consumer $i$ at time $t$ from purchasing good $j$. The vector $\boldsymbol{x}_{\boldsymbol{j} \boldsymbol{t}}$ defines the characteristics of good $j$ other than price, $p$, at time $t$. The term $\xi_{j t}$ denotes a product quality characteristic that is known to consumers and producers but that is unknown to the econometrician and $\epsilon_{i j t}$ denotes an i.i.d. (across consumers and products) extreme value distributed unobserved (to the econometrician) quality component. ${ }^{14}$ In the present case, a potentially important quality characteristic for example is magazine design and layout. The parameter $\tau_{t}$ represents a time-dependent utility component that is identical across consumers and magazines, for example general shifts in consumer taste. Consumer $i$ 's mean utility, $\delta_{j t}$, from consumption of good $j$ at time $t$ is hence given by

$$
\delta_{j t}=\boldsymbol{x}_{\boldsymbol{j} \boldsymbol{t}} \boldsymbol{\beta}+\alpha p_{j t}+\tau_{t}+\xi_{j t}
$$

In the present panel data setting, the error term $\xi_{j t}$ can be decomposed in an individual-specific component, $\gamma_{i}$, and an i.i.d. error mean zero, variance $\sigma_{\varepsilon}$ distributed component that varies across consumers and time, $\varepsilon_{i t}$, leading to the following error decomposition:

$$
\xi_{j t}=\gamma_{j}+\varepsilon_{j t}
$$

The way error component $\gamma_{j}$ is treated constitutes either the 'fixed effects' or the 'random effects' model. If $\gamma_{j}$ is considered as an unknown parameter specific to each product $j$, this leads to the fixed effects model. If $\gamma_{j}$ is assumed to be a random variable with mean $\mu$ and variance $\sigma_{\gamma}$, this leads to the random effects model. The fixed effects model does not place a priori restrictions on the relationship between the explanatory variables and the idiosyncratic error component, while the random effects model assumes that there is no correlation

\footnotetext{
${ }^{14}$ Note that the vector of taste parameters $\boldsymbol{\beta}$ and the price coefficient $\alpha$ are assumed to be constant across consumers. This is the main difference to random coefficient models where the taste parameters are treated as consumer-specific, usually made dependent on consumer characteristics such as age, gender, income etc.
} 
between them. ${ }^{15}$

The i.i.d. extreme value distributed error term $\epsilon_{i j t}$ generates the following wellknown Logit form of market shares:

$$
s_{j t}\left(\delta_{j t}\right)=\frac{\exp \left(\delta_{j t}\right)}{\sum_{k=1}^{N} \exp \left(\delta_{k t}\right)},
$$

where $N$ denotes the total number of products and market share $s_{j t}$ is defined as the number of copies sold by magazine $j$ at time time relative to total market size. Market size is defined as total female population in Germany older than 14 years at time $t .{ }^{16}$ That is, $s_{0 t}=1-\sum_{k=1}^{N} s_{k t}$, where the subscript 0 denotes the outside good. The utility obtained from the consumption of the outside good is normalized to be equal to zero so that

$$
s_{j t}\left(\delta_{j t}\right)=\frac{\exp \left(\delta_{j t}\right)}{1+\sum_{k \neq 0} \exp \left(\delta_{k t}\right)} \quad \text { and } \quad s_{0 t}\left(\delta_{j t}\right)=\frac{1}{1+\sum_{k \neq 0} \exp \left(\delta_{k t}\right)} .
$$

Rearranging terms and taking natural logarithms leads to Logit-type market share estimation equations:

$$
\ln \left(s_{j t}\right)-\ln \left(s_{0 t}\right) \equiv \delta_{j t}=x_{j t} \beta+\alpha p_{j t}+\tau_{t}+\xi_{j t} .
$$

A general drawback of the Logit model is that it does not allow for correlation of consumer taste across products $j$, a property that implies that own and crossprice elasticities as well as the effects of other product characteristics depend upon product $j$ 's market shares only and are also independent of the product group product $j$ belongs to. The nested logit model allows for considering differences across product groups while retaining the i.i.d. extreme value assumption of the unobserved consumer utility component $\epsilon_{i j t}$, thereby generating a closed-form solution for market shares as in the Logit case.

Defining $d_{j g}$ a dummy variable which is coded one if magazine $j$ belongs to group $g=20-29,30-39,40-49,70 p$, in the Nested Logit model consumer utility is given by:

$$
u_{i j t}=\delta_{j}+\sum_{g}\left[d_{j g} \zeta_{j g}\right]+(1-\sigma) \epsilon_{i j t}
$$

\footnotetext{
${ }^{15}$ If the explanatory variables and the idiosyncratic error component are correlated with one another, the fixed effects model is consistent and efficient, while the random effects model is inconsistent. If there is no correlation between the explanatory variables and the idiosyncratic error component, the fixed effects model is consistent but inefficient while the random effects model is consistent and efficient.

${ }^{16}$ This data is taken from Statistisches Bundesamt (various issues, 1990-1999).
} 
where $\epsilon_{i j t}$ is defined as above, $\zeta$ is common to all products in group $g$ and $\sigma$ denotes the group correlation of utility levels. If $\sigma=1$, products are perfect substitutes and if $\sigma=0$, products are symmetric. The market shares in the nested Logit model are as follows:

$$
s_{j t}\left(\boldsymbol{\delta}_{\boldsymbol{j}}, \sigma\right)=\frac{\exp \left(\frac{\delta_{j}}{1-\sigma}\right)}{D_{g}^{\sigma} \sum_{g} D_{g}^{1-\sigma}},
$$

with $D_{g}=\sum_{j \in \text { product group } g} \exp \left(\delta_{j} /(1-\sigma)\right)$.

With mean utility of the outside good normalized to zero, the market share estimation equation is

$$
\ln \left(s_{j t}\right)-\ln \left(s_{0 t}\right)=\boldsymbol{x}_{\boldsymbol{j} \boldsymbol{t}} \boldsymbol{\beta}+\alpha p_{j}+\sigma \ln \left(\bar{s}_{j \mid g}\right)+\tau_{t}+\xi_{j t},
$$

where $\bar{s}_{j \mid g}$ denotes the share of product $j$ in product group $g$.

\subsection{Identification}

If there was no unobserved quality component $\xi_{j t}$, estimation of Equation (6) would simply require running OLS of the differences in log market shares on the magazine characteristics including price. Since prices are a function of $\xi_{j t}$, an identification problem arises. The traditional solution to the identification problem is to use instrumental-variables (IV) techniques. To my knowledge, this is the approach followed by most of the literature on the estimation of differentiated product demand models so far (e.g. Moral and Jaumandreu 1998; Trajtenberg 1989; Verboven 1996; Wojcik 2000). However, identification in the logit model can also be achieved by explicitly using the time series dimension of panel data. Recall the error term decomposition (3), $\xi_{j t}=\gamma_{j}+\varepsilon_{j t}$. If $\varepsilon_{j t}$ follows an $\operatorname{AR}(1)$ process with correlation coefficient $\rho, \varepsilon_{j t}=\rho \varepsilon_{j t-1}+\varsigma_{j t}$, and $\varsigma_{j t}$ is orthogonal to magazine prices (and quality characteristics), the price coefficient $\alpha$ is identified without IV technique under the weak assumption that $E\left[\varepsilon_{j t-1} p_{j t}\right]=0$.

In the nested Logit model, within-group market share $\bar{s}_{j \mid g}$ is endogenous by construction and needs to be instrumented.

Six different econometric models are estimated: (i) a IV random effect Logit model, (ii) a IV fixed effect Logit model, (iii) a AR(1) random effect Logit model, (iv) a AR(1) fixed effect Logit model, (v) a IV random effect nested Logit model and (vi) a IV fixed effect nested Logit model. Due to the fact that the fixed effect 
models are rejected by Hausman (1978) specification tests, estimation results for the fixed effects models are not presented here.

Descriptive statistics of the variables involved in the estimations are shown in Appendix B.

\subsection{Empirical specification}

The specification of the vector of product characteristics, $\boldsymbol{x}_{\boldsymbol{j} \boldsymbol{t}}$, contains the following variables: (i) magazine age and its square; (ii) the natural logarithm of the number of magazine pages per issue and its square, $\ln$ (\# of pages) and

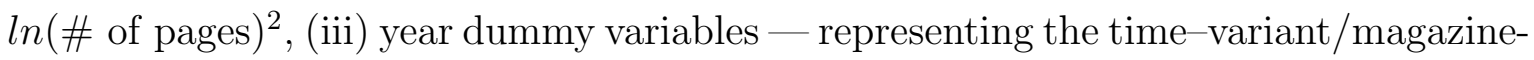
invariant quality component $\tau_{t}$ — and (iv) a dummy variable for website provision, Website. ${ }^{17}$

Magazine age measures how long the magazine has been on the market. On the one hand, it takes time until consumers get to know the magazine and until the editorial staff is able to precisely identify its target group needs, implying that age has a positive effect on market shares. One the other hand, 'organizational geriatics' (Agarwal and Gort 1996), caused e.g. by an aging editorial staff that is faced by an on the average constantly aged readership, may lead to a decrease in market shares. The inclusion of a linear and a squared age term allows to calculate women's magazines 'senility points'.

The inclusion of the number of magazine pages in the specification is motivated by the fact that readers may appreciate many pages, but obtain disutility if the number of pages exceeds a certain limit which for example makes it inconvenient to carry the magazine around due to increased weight for example.

The inclusion of the website dummy variable is straightforward given the finding of Section 2 that website provision serves as a quality signal.

The data fortunately provide a rich set of instruments for price and within group market share. Potential instruments for price are (i) cost variables that are not already contained in the vector of product characteristics and (ii) cost and quality characteristics of other magazines (Berry 1994). Likewise, potential instruments for within group market share are cost and quality characteristics of the other

\footnotetext{
${ }^{17}$ The age variables are not identified separately from the fixed effects in the fixed effects model since the specification also includes time dummy variables. For that reason, they are left out in the fixed effects models.
} 
magazines in the own magazine group.

\section{Instrument for magazine prices: cost-side variables}

The following cost-side variables are used as instruments for price: (i) the natural logarithm of the number of titles issued by the own publishing house and its square since publishers may be able to gain from production spillovers generated by other magazine titles edited by the publishing house. This positive effect might be counteracted, however, if the organization grows 'too big' in the sense that organization costs become excessive or that multiple plants, including ineffective ones, are maintained. (ii) The share of women's magazines published by the own publishing house in the total number of magazines published by the own publishing house. The higher the ratio is, the lower should marginal production cost be.

\section{Instrument for magazine prices: characteristics of other magazines}

Other instruments for magazine prices are the averages of quality characteristics of magazines other than the magazine under consideration, namely (iii) average magazine age and (iv) the average number of magazine pages. Finally, the mean order of entry into the four magazines subgroups (excluding the magazine in question) is used as an instrument for price as well. To construct this variable, for each magazine a variable reflecting its order of entry into each subgroup of the women's magazine market is constructed.

\section{Instrument for within group market shares}

Within-group shares $\bar{s}_{j \mid g}$ is instrumented by the following set of variables: (i) 'potential within group market reach' of magazines other than magazine $j$ and (ii) the order of entry in magazine group $g$. 'Potential market reach' is a variable which is measured as the ratio of the number of potential magazine readers relative to the total German population. It is based on a large survey conducted by AG.MA. The argument behind the inclusion of this variable is that the larger potential within group market share is, the larger should actual market share be. The argument for the inclusion for the order of entry is basically the same as for the inclusion of magazine age in the vector of product characteristics with the main difference being that the order of entry is uncorrelated with current prices. 


\subsection{Estimation results}

The estimation results for three Logit models are presented in Table 7: (i) an IV random effects Logit model, (ii) an AR(1) random effects Logit model and (iii) an AR(1) fixed effects Logit model. Fixed effects are rejected for the IV logit model so that the related estimation results are not displayed here. ${ }^{18}$

The instrumental-variables models are estimated using two stage technique as described by Baltagi (1995, Ch. 7.1). Appendix C displays the first-stage estimation results for the price equation and the Logit model, while Appendix D shows first-stage estimation results for the nested Logit model. Both Appendices are informative with respect to the quality of the instrumentation. They both show that the instruments are both individually and jointly insignificant in the demand equations but highly significant in the instrumental-variables equations. Appendix C and Appendix D hence confirm the choice of the instrumentation.

By and large, the estimation results for the three different econometric models are surprisingly similar, both quantitatively and qualitatively. The coefficient of price is between -0.0609 and -0.1131 and is, with exception of the IV Logit model where it is significantly different from zero at the ten per cent marginal significance level only, very precisely estimated.

Website provision significantly affects magazine demand only in the IV Logit model specification. The effect is positive, indicating that website provision is valued by consumers as a quality characteristic and hence props up magazine demand. The robustness of this finding is challenged, however, by the insignificant effects of website provision in all other specifications being estimated, including the IV nested logit model.

Magazine age does not have a significant effect in all of the random effects specification displayed in Table 7. The number of pages per issue has a convex effect on relative market share with a minimum reached at magazine sizes between 105 and 144 pages. This result is surprising at least at first sight. The explanation for a convex effect of magazine size on relative demand is that the low-priced magazines which come with a comparatively low page size per issue possess a relatively high market share. The year dummy variables are jointly significantly different from zero, suggesting that there are significant changes in market structure over time. The signs and magnitude of the year-dummy variables indicate

\footnotetext{
${ }^{18}$ Note that the magazine 'Elle' dropped out of the estimations due to missing values in some of the instrumental-variables.
} 
a marked increased in demand in 1991, the year after the German reunification, and a continuous decline in demand after 1994.

The estimated autocorrelation coefficient, $\rho$, is large in magnitude. Critical values for tests for autocorrelation in panel data models are, however, not tabulated so that an explicit test for autocorrelation does not readily apply here (Baltagi and Wu 1999).

Nested Logit estimation results are presented in Table 8. Although the nested

Table 7: Estimation results for Equation (6)

\begin{tabular}{|c|c|c|c|c|c|c|}
\hline & \multicolumn{2}{|c|}{ IV random effects } & \multicolumn{2}{|c|}{ AR(1) random effects } & \multicolumn{2}{|c|}{ AR(1) fixed effects } \\
\hline & Coeff. & Std. err. & Coeff. & Std. err. & Coeff. & Std. err. \\
\hline$\alpha$ & $-0.0869^{*}$ & 0.0480 & $-0.1131^{* * *}$ & 0.0181 & $-0.0609^{* * *}$ & 0.0196 \\
\hline Age/100 & 0.2440 & 0.4836 & -0.4596 & 0.3821 & & \\
\hline $\mathrm{Age}^{2} / 100$ & $-0.0048^{*}$ & 0.0028 & -0.0039 & 0.0032 & & \\
\hline $\ln (\#$ of pages $)$ & $-1.3270^{* *}$ & 0.6319 & $-1.3257^{* * *}$ & 0.5074 & $-1.5346^{* *}$ & 0.6267 \\
\hline $\ln (\# \text { of pages })^{2}$ & $0.1372^{* *}$ & 0.0692 & $0.1424^{* * *}$ & 0.0558 & $0.1543^{* *}$ & 0.0665 \\
\hline Website & $0.0895^{* * *}$ & 0.0358 & 0.0416 & 0.0313 & 0.0255 & 0.0294 \\
\hline 1990 & $0.1781^{* * *}$ & 0.0594 & & & & \\
\hline 1991 & $0.2693^{* * *}$ & 0.0529 & $0.1249^{* * *}$ & 0.0158 & $0.1562 * * *$ & 0.0138 \\
\hline 1992 & $0.2677^{* * *}$ & 0.0461 & $0.1416^{* * *}$ & 0.0195 & $0.1865^{* * *}$ & 0.0174 \\
\hline 1993 & $0.2496^{* * *}$ & 0.0403 & $0.1393^{* * *}$ & 0.0212 & $0.1927^{* * *}$ & 0.0196 \\
\hline 1994 & $0.2326^{* * *}$ & 0.0367 & $0.1353^{* * *}$ & 0.0217 & $0.1961^{* * *}$ & 0.0207 \\
\hline 1995 & $0.1872^{* * *}$ & 0.0324 & $0.1113^{* * *}$ & 0.0217 & $0.1735^{* * *}$ & 0.0207 \\
\hline 1996 & $0.1449^{* * *}$ & 0.0295 & $0.0891^{* * *}$ & 0.0210 & $0.1454^{* * *}$ & 0.0197 \\
\hline 1997 & $0.1275^{* * *}$ & 0.0279 & $0.0829^{* * *}$ & 0.0195 & $0.1310^{* * *}$ & 0.0184 \\
\hline 1998 & $0.0549^{* *}$ & 0.0255 & $0.0282^{*}$ & 0.0173 & $0.0630^{* * *}$ & 0.0160 \\
\hline 1999 & $0.0411^{*}$ & 0.0236 & 0.0205 & 0.0131 & $0.0336^{* * *}$ & 0.0119 \\
\hline Constant & -1.1070 & 1.4858 & -0.9017 & 1.1459 & & \\
\hline \multicolumn{7}{|l|}{ Tests for joint significance } \\
\hline Age & 3.8400 & 0.1467 & 18.7400 & 0.0000 & & \\
\hline $\ln (\#$ of pages $)$ & 4.9200 & 0.0853 & 6.9800 & 0.0305 & 3.3900 & 0.0352 \\
\hline Year dummies & 93.4300 & 0.0000 & 85.9400 & 0.0000 & 15.3900 & 0.0000 \\
\hline Specification & 374.0900 & 0.0000 & 181.6600 & 0.0000 & 19.1600 & 0.0000 \\
\hline \multicolumn{7}{|c|}{ Utility-maximizing age and utility-minimizing \# of pages } \\
\hline Age & 25.4 & & & & & \\
\hline \multirow{2}{*}{\multicolumn{7}{|c|}{ Random vs. fixed effects specification issues and $\rho$-estimate }} \\
\hline & & & & & & \\
\hline Random vs. fixed effects & 8.7600 & 0.8460 & & & & \\
\hline Corr(fixed effects, expl. var.) & 0.0000 & & 0.0000 & & 0.3827 & \\
\hline $\mathrm{F}$-test fixed effects $=0$ & & & & & 35.2200 & \\
\hline$\rho$ & & & 0.7244 & & 0.7640 & \\
\hline \multicolumn{7}{|c|}{ Within, between and overall $R^{2}$} \\
\hline Within & 0.5429 & & 0.5353 & & 0.4229 & \\
\hline Between & 0.2177 & & 0.2381 & & 0.3454 & \\
\hline Overall & 0.2294 & & 0.3236 & & 0.3345 & \\
\hline \# of obs. and \# of groups & & & & & & \\
\hline \# of obs. & 368 & & 368 & & 368 & \\
\hline \# of groups & 41 & & 41 & & 41 & \\
\hline
\end{tabular}

Logit model is the more flexible approach with respect to substitution patterns so that similarity of results cannot be expected a priori, the estimated coefficients are very similar to the ones displayed in Table 8.

Website provision has a positive, yet insignificant, effect on magazine demand. The price-coefficient is -0.1066 and is hence in the same range as in the simple Logit models. The within-group share coefficients $\sigma$ is highly significantly different from zero and quite large in absolute magnitude, suggesting that there is considerable within-group correlation of utilities.

Magazine age again has a concave effect on mean utility (maximum: 48 years) and 
the number of pages has a convex effect on mean utility (minimum: 121 pages). The same time-pattern in magazine demand as for the simple Logit model are found.

Although website provision does not have a significant effect on magazine demand, its coefficient is positive and relatively quite large in all specifications. Since the dependent variable is specified in log, a coefficient of 0.0297 as in the IV nested Logit model implies an increase in market shares of 2.97 percent relative to the market share of the outside good. Moreover, one might expect that the effect of website provision is larger for magazines aiming at younger than for magazine focussing on older women. Therefore, column 'Counter-factual website effect' in Table 9 displays, (i) for magazines that provide a website the quantitative effect of going offline (under the assumption that the other magazines do not change their website strategy) and (ii) for magazines that are offline the quantitative effect of going online (again under the assumption that the other magazines do not change their website strategy). Hence, this column provides counter-factual evidence on the effect of presence/absence of website provision. It turns out the the effect of going online does not differ much across magazines that actually are online. The quantitative effect indicates demand decreases between 0.26 and 0.32 per cent. Much more differences of website effects are present for magazines that are not online. Unsurprisingly, the website effect is smallest for magazines targeting at consumers aged 70 and above. It is largest for magazines focussing on purchasers aged between 30 and 39 years. Interestingly, the third-largest winner of a potential website launch, 'Bild der Frau', actually went online in 2001 (www.bildderfrau.de). It's potential market share gain is 0.33 per cent. Another potential winner that launched a website in 2001 is 'Für Sie' (www.fuersie.de). The market share gain is 0.29 per cent in that case.

Table 9 also displays own-price elasticities for the IV nested Logit specification. Own-price elasticities are given by: ${ }^{19}$

$$
\eta_{s_{j t}, p_{j t}}=\frac{1}{1-\sigma}\left[1-\sigma \bar{s}_{j t \mid g}-(1-\sigma) s_{j t}\right] \alpha p_{j t}
$$

so that the point estimate of 0.25 for $\sigma$ implies that own-price elasticities depend to a larger extent on the absolute market shares, $s_{j t}$, rather than on within-group market shares, $\bar{s}_{j t \mid g}$. All figures displayed in Table 9 correspond to 2000. By construction of the nested Logit model, own-price elasticities are highly negatively

\footnotetext{
${ }^{19}$ The own-price elasticities for the Logit model are obtained by setting $\sigma=0$.
} 
correlated with cover prices.

Finally, I experimented with alternative specifications for website provision. These specifications replaced the dummy variable for website provision by (i) interactions between magazine group dummy variables and the indicator variable for website provision, (ii) interacting magazine prices with a dummy variables for ever having launched a website and (iii) interacting magazine prices with a dummy variables for contemporaneous website provision. None of these alternative specifications leads to statistically significant effects of website provision on market shares.

\section{Conclusion}

Descriptive and econometric evidence on the effect of website provision on market shares suggests a simple answer to the initially asked question about the effects of going online on market demand. Neither is evidence provided that website provision props up magazine demand nor that it leads to a decrease in market shares.

The empirical evidence is provided for the German women's magazine market, a particularly large segment of the German publishing market which is characterized by fierce competition among magazine titles. Eight out of 41 magazines run websites in 2000, a number that steadily increased since 1996 when the first three magazines went online. By and large, magazines which provide a website are those with a consumer structure that uses the internet more often at home and/or at work and also is more likely to have internet access in general compared to the magazines that are still offline.

An analysis of the women's magazines websites shows that magazines mainly use their website to provide information that is supplementary to the contents of the current print issue and to advertise the current print issue as well as other products published by their publishing houses. With regard to these facts, consumer substitution in favor of the online media and in disfavor of the printed media does not appear to be reasonable.

Instead, website provision seems to serve as a quality signal to consumers. It is hence treated as a quality characteristic within a differentiated product demands framework in the econometric analysis. Panel data estimations including a to- 
tal of 368 observations on 41 magazines observed between 1990 to 2000 indicate that website provision does not significantly affect women's magazines market shares. A counter-factual analysis that asks what happened to demand if an online magazine went back offline and vice versa shows, however, that changes in market shares due to website provision are in some cases quite sizeable. If a magazine that already is online and withdraws its website, the estimated loss in market shares is around 0.3 per cent. Potential gains from launching a website are largest for magazines targeting women aged between 30 and 39. Interestingly, one of the largest potential winners, 'Bild der Frau', actually went online in 2001. Future research will include an analysis of the news magazine market, where substitution between internet information and magazine information is more likely due to the large overlap in contents between the online and the printed media. 
Table 8: Estimation results for Equation (9)

\begin{tabular}{|c|c|c|}
\hline & \multicolumn{2}{|c|}{ IV random effects model } \\
\hline & Coeff. & Std.err. \\
\hline$\alpha$ & $-0.1066^{*}$ & 0.0575 \\
\hline$\sigma$ & $0.2540^{* *}$ & 0.1195 \\
\hline Age/100 & 0.5329 & 0.4874 \\
\hline $\mathrm{Age}^{2} / 100$ & $-0.0055^{* *}$ & 0.0028 \\
\hline $\ln (\#$ of pages $)$ & $-1.2892^{* *}$ & 0.6312 \\
\hline $\ln (\# \text { of pages })^{2}$ & $0.1344^{* *}$ & 0.0691 \\
\hline Website & 0.0297 & 0.0447 \\
\hline 1990 & $0.1111^{*}$ & 0.0651 \\
\hline 1991 & $0.2162^{* * *}$ & 0.0567 \\
\hline 1992 & $0.2125^{* * *}$ & 0.0514 \\
\hline 1993 & $0.2012^{* * *}$ & 0.0452 \\
\hline 1994 & $0.1897^{* * *}$ & 0.0410 \\
\hline 1995 & $0.1557^{* * *}$ & 0.0350 \\
\hline 1996 & $0.1206^{* * *}$ & 0.0311 \\
\hline 1997 & $0.1036^{* * *}$ & 0.0296 \\
\hline 1998 & 0.0417 & 0.0260 \\
\hline 1999 & 0.0373 & 0.0236 \\
\hline Constant & -0.5616 & 1.5033 \\
\hline \multicolumn{3}{|c|}{ Tests for joint significance } \\
\hline Age & 4.05 & 0.1318 \\
\hline $\ln (\#$ of pages $)$ & 4.49 & 0.1058 \\
\hline Year dummies & 66.99 & 0.0000 \\
\hline Specification & 379.41 & 0.0000 \\
\hline \multicolumn{3}{|c|}{ Utility-maximizing age and utility-minimizing \# of pages } \\
\hline Age & 48.2 & \\
\hline \# of pages & 121.0 & \\
\hline \multicolumn{3}{|c|}{ Tests for random vs. fixed effects specification } \\
\hline Random vs. fixed effects & 13.77 & 0.6159 \\
\hline LR-test random effects & 1385.57 & 0.0000 \\
\hline \multicolumn{3}{|c|}{ Within, between and overall $R^{2}$} \\
\hline Within & 0.5467 & \\
\hline Between & 0.2613 & \\
\hline Overall & 0.2789 & \\
\hline \multicolumn{3}{|c|}{ \# of obs. and \# of groups } \\
\hline \# of obs. & 368 & \\
\hline \# of groups & 41 & \\
\hline
\end{tabular}


Table 9: Counter-factual website effect, website provision, grouping, price and own-price elasticity for 2000

\begin{tabular}{|c|c|c|c|c|c|}
\hline & $\begin{array}{r}\text { Counter- } \\
\text { factual } \\
\text { website } \\
\text { effect } \\
(\text { in } \%) \\
\end{array}$ & Website & Group & $\begin{array}{r}\text { Price } \\
\text { (in DM) } \\
\end{array}$ & $\begin{array}{r}\text { Own- } \\
\text { price } \\
\text { elasticity } \\
(\text { in } \%) \\
\end{array}$ \\
\hline 7 Tage & 0.0677 & no & $70 \mathrm{p}$ & 2.5 & -0.3550 \\
\hline Allegra & -0.2635 & yes & $20-29$ & 5 & -0.6893 \\
\hline Amica & -0.2685 & yes & $20-29$ & 6 & -0.8113 \\
\hline Bella & 0.3654 & no & $30-39$ & 2.4 & -0.3330 \\
\hline Bild der Frau & 0.3342 & no & $30-39$ & 1.4 & -0.1748 \\
\hline Brigitte & -0.2717 & yes & $40-49$ & 4 & -0.5196 \\
\hline Cosmopolitan & -0.2787 & yes & $20-29$ & 5 & -0.6744 \\
\hline Das Goldene Blatt & 0.2077 & no & $70 \mathrm{p}$ & 2.5 & -0.3526 \\
\hline Das Neue & 0.2203 & no & $70 p$ & 2.6 & -0.3637 \\
\hline Das Neue Blatt & 0.2158 & no & $70 p$ & 2.5 & -0.3392 \\
\hline Die Aktuelle & 0.2108 & no & $70 p$ & 2.6 & -0.3615 \\
\hline Die Neue Frau & 0.2531 & no & $70 \mathrm{p}$ & 1.6 & -0.2260 \\
\hline Echo der Frau & 0.2425 & no & $70 p$ & 2.5 & -0.3501 \\
\hline Frau aktuell & 0.2185 & no & $70 \mathrm{p}$ & 2.5 & -0.3511 \\
\hline Frau im Leben & 0.2335 & no & $70 \mathrm{p}$ & 3.5 & -0.4965 \\
\hline Frau im Spiegel & 0.2303 & no & $70 p$ & 2.7 & -0.3734 \\
\hline Frau mit Herz & 0.2201 & no & $70 p$ & 2.5 & -0.3542 \\
\hline Freizeit Revue & 0.2034 & no & $70 \mathrm{p}$ & 2.6 & -0.3517 \\
\hline Freundin & -0.3213 & yes & $40-49$ & 4 & -0.5371 \\
\hline Für Sie & 0.2947 & no & $40-49$ & 4 & -0.5374 \\
\hline Glücks Revue & 0.2239 & no & $70 \mathrm{p}$ & 2 & -0.2811 \\
\hline Heim und Welt & 0.2480 & no & $70 \mathrm{p}$ & 2.3 & -0.3269 \\
\hline Journal für die Frau & 0.2532 & no & $40-49$ & 4 & -0.5492 \\
\hline Laura & 0.3162 & no & $30-39$ & 1.5 & -0.2063 \\
\hline Lea & 0.3164 & no & $30-39$ & 1.5 & -0.2100 \\
\hline Lisa & 0.3168 & no & $30-39$ & 1.5 & -0.2046 \\
\hline Mach mal Pause & 0.2334 & yes & $70 \mathrm{p}$ & 2.1 & -0.2952 \\
\hline Madame & 0.2347 & no & $40-49$ & 11 & -1.5560 \\
\hline Marie Claire & 0.2391 & no & $20-29$ & 7 & -0.9747 \\
\hline Maxi & 0.2572 & no & $20-29$ & 7 & -0.9514 \\
\hline Mini & 0.3237 & no & $30-39$ & 1.4 & -0.1957 \\
\hline Neue Post & 0.2411 & no & $70 \mathrm{p}$ & 2.5 & -0.3346 \\
\hline Neue Welt & 0.2390 & no & $70 \mathrm{p}$ & 2.5 & -0.3502 \\
\hline Neue Woche & 0.2339 & no & $70 \mathrm{p}$ & 1.5 & -0.2090 \\
\hline Petra & -0.2903 & yes & $40-49$ & 5 & -0.6900 \\
\hline Ratgeber Frau und Familie & 0.1878 & no & $40-49$ & 3.8 & -0.5256 \\
\hline Tina & 0.3799 & no & $30-39$ & 2.4 & -0.3170 \\
\hline Viel Spass & 0.2630 & no & $70 \mathrm{p}$ & 1 & -0.1379 \\
\hline Vital & 0.3250 & no & $20-29$ & 4 & -0.5413 \\
\hline Vogue & -0.3012 & yes & $20-29$ & 11 & -1.5403 \\
\hline
\end{tabular}




\section{Appendix A: Data sources}

Except for the information on consumer characteristics (which were made available to me upon request), the data components used in this paper are publicly available. In order to collect information on the German magazine market in general and on women's magazines in particular, the following website proved to be useful:

http://www.pz-online.de/: Contains key figures on German magazines and publishing houses; was used to match magazines and publishing houses.

http://www.media-daten.de/: Same information as http://www.pz-online.de/ but also considers newspapers. publishing houses.

http://www.gujmedia.de/: Contains a media encyclopedia, information on Gruner + Jahr product and research report downloads on the German magazine market. publishing houses. publishing houses.

http://www.agma-mmc.de: Describes the original data sources for the information on magazine characteristics. publishing houses.

http://www.awa-online.de/: Describes the original data sources for the information on magazine purchasers characteristics.

The bulk on information on the total number of titles published by the women's magazines publishing houses was collected from the publishing houses' websites. The table below list the publishing houses along with their websites ('no website' means that the corresponding publishing house did not provide a website by early October 2001).

\begin{tabular}{lc}
\hline Publishing house & Website \\
\hline Axel Springer Verlag & www.asv.de \\
Burda Media & www.burda.de \\
Condé Nast Verlag GmbH & www.condenast.de \\
Gong Verlag & www.gonginfo.de \\
Heinrich Bauer Verlag & www.hbv.de \\
Gruner + Jahr AG \& Co. & www.gujmedia.de \\
Jahreszeiten-Verlag & www.jalag.de \\
J. Weck GmbH u. Co. KG Verlag & www.weck.de \\
Klambt Verlag & no website \\
MAGAZINPRESSE Verlag GmbH Zeitschriften \& Co KG & no website \\
MVG Medienverlagsgesellschaft mbH \& Co. & www.mvg.de \\
Verlagsgruppe Lübbe GmbH \& Co. KG & www.media.bastei.de \\
Verlagsgruppe Milchstrae & www.milchstrasse.de \\
Weltbild Verlag GmbH & www.weltbild.com \\
WZV Westdeutsche Zeitschriftenverlag GmbH \& Co.KG & no website \\
\hline
\end{tabular}




\section{Appendix B: Descriptive statistics}

\begin{tabular}{lrrrr}
\hline & Mean/ & \multicolumn{3}{c}{ Standard deviation } \\
& share & overall & between & within \\
\hline Endogenous variables & & & & \\
$\bar{s}_{j \mid g t}$ & -2.4282 & 0.8150 & 0.8056 & 0.1493 \\
$p_{j t}$ & 3.4723 & 2.2903 & 2.2248 & 0.2982 \\
$l n\left(s_{j t} / s_{0 t}\right)$ & -4.3698 & 0.7379 & 0.7092 & 0.1376 \\
Quality characteristics vector & $\boldsymbol{x}_{\boldsymbol{j} \boldsymbol{t}}$ & & \\
Age/100 & 0.3120 & 0.2934 & 0.2880 & 0.0297 \\
ln $\#$ of pages $)$ & 4.7142 & 0.5731 & 0.5884 & 0.0709 \\
Website & 0.0652 & 0.2472 & 0.1981 & 0.1780 \\
Instruments for price & & & & \\
ln $\#$ of titles) & 2.2855 & 0.8546 & 0.8030 & 0.1540 \\
Title ratio & 0.3628 & 0.2198 & 0.2005 & 0.0614 \\
Average age & 31.1957 & 1.1799 & 0.8262 & 0.7866 \\
Average order & 5.9864 & 0.5400 & 0.2868 & 0.5034 \\
Average \# of pages & 132.1647 & 72.4143 & 71.1790 & 7.1561 \\
Instruments for $s_{j \mid g t}$ & & & & \\
Order of entry & 5.9864 & 4.4216 & 5.0350 & 0.0000 \\
Average market reach & 2.5580 & 1.1318 & 1.0067 & 0.5395 \\
\hline
\end{tabular}




\section{Appendix C: first stage logit estimates}

\begin{tabular}{|c|c|c|c|c|}
\hline & \multicolumn{2}{|c|}{$\begin{array}{l}\text { Dep. variable: } \ln \left(s_{j} / s_{0}\right) \\
\text { Random effects model }\end{array}$} & \multicolumn{2}{|c|}{$\begin{array}{l}\text { Dep. variable: price } \\
\text { Random effects model }\end{array}$} \\
\hline & Coeff. & Std.err. & Coeff. & Std.err. \\
\hline Age/100 & 1.2539 & 1.0325 & 2.0706 & 1.6119 \\
\hline $\mathrm{Age}^{2} / 100$ & $-0.0106^{*}$ & 0.0059 & -0.0094 & 0.0091 \\
\hline $\ln (\#$ of pages $)$ & $-1.0926^{*}$ & 0.6166 & $-2.8254^{*}$ & 1.6087 \\
\hline $\ln (\# \text { of pages })^{2}$ & 0.1034 & 0.0660 & $0.3925^{* *}$ & 0.1712 \\
\hline Website & $0.0971^{* * *}$ & 0.0326 & $-0.2248^{* * *}$ & 0.0869 \\
\hline 1990 & -0.2432 & 0.5018 & 1.2698 & 1.1581 \\
\hline 1991 & -0.0959 & 0.5457 & 1.8935 & 1.2493 \\
\hline 1992 & -0.2123 & 0.5250 & 1.6420 & 1.2113 \\
\hline 1993 & -0.2229 & 0.4451 & 1.1904 & 1.0241 \\
\hline 1994 & -0.1266 & 0.3286 & 0.7627 & 0.7543 \\
\hline 1995 & -0.0035 & 0.3768 & $1.6900^{* *}$ & 0.8498 \\
\hline 1996 & -0.0425 & 0.3507 & $1.5860^{* *}$ & 0.7925 \\
\hline 1997 & -0.2242 & 0.3362 & 1.0574 & 0.7739 \\
\hline 1998 & -0.2131 & 0.2339 & 0.6032 & 0.5344 \\
\hline 1999 & 0.1562 & 0.1088 & 0.2770 & 0.2066 \\
\hline $\ln (\#$ of titles $)$ & 0.1306 & 0.1227 & $-1.6923^{* * *}$ & 0.3035 \\
\hline $\ln (\# \text { of titles })^{2}$ & -0.0297 & 0.0235 & $0.2976^{* * *}$ & 0.0610 \\
\hline Share in women's mag. & -0.0744 & 0.1343 & $-0.8504^{* * *}$ & 0.3432 \\
\hline Average age & 0.0944 & 0.1003 & $0.3823^{* *}$ & 0.1872 \\
\hline Average entry order & -0.3300 & 0.3488 & $1.5030^{*}$ & 0.8052 \\
\hline Average \# of pages & -0.0001 & 0.0007 & $0.0059^{* * *}$ & 0.0017 \\
\hline Constant & -2.7285 & 4.6163 & -12.9558 & 9.6871 \\
\hline \multicolumn{5}{|c|}{ Tests for joint significance } \\
\hline Quality characteristics & 67.21 & 0.0000 & 120.57 & 0.0000 \\
\hline Price-instruments & 7.05 & 0.3162 & 54.16 & 0.0000 \\
\hline $\ln (\#$ of titles $)$ & 1.60 & 0.4499 & 31.10 & 0.0000 \\
\hline Specification & 380.29 & 0.0000 & 318.79 & 0.0000 \\
\hline \multicolumn{5}{|c|}{ Random vs. fixed effects specification issues and $\rho$-estimate } \\
\hline Random vs. fixed effects & 31.96 & 0.0437 & 12.01 & 0.9158 \\
\hline LM-test random effects & 1385.75 & 0.0000 & 877.39 & 0.0000 \\
\hline \multicolumn{5}{|c|}{ Within, between and overall $R^{2}$} \\
\hline Within & 0.5508 & & 0.3897 & \\
\hline Between & 0.1476 & & 0.7900 & \\
\hline Overall & 0.1785 & & 0.7710 & \\
\hline \multicolumn{5}{|c|}{ \# of obs. and \# of groups } \\
\hline \# of obs. & 368 & & 368 & \\
\hline \# of groups & 41 & & 41 & \\
\hline
\end{tabular}




\section{Appendix D: first stage Nested Logit estimates}

\begin{tabular}{|c|c|c|c|c|c|c|}
\hline & \multicolumn{2}{|c|}{ Dep. var.: $\ln \left(s_{j} / s_{0}\right)$} & \multicolumn{2}{|c|}{ Dep. var.: price } & \multicolumn{2}{|c|}{ Dep. var.: $\ln \left(\bar{s}_{j \mid g}\right)$} \\
\hline & Coeff. & Std.err. & Coeff. & Std.err. & Coeff. & Std.err. \\
\hline Age/100 & 0.0105 & 0.0116 & 0.0151 & 0.0177 & -0.0075 & 0.0115 \\
\hline $\mathrm{Age}^{2} / 100$ & $-0.0001^{*}$ & 0.0001 & -0.0001 & 0.0001 & 0.0000 & 0.0001 \\
\hline $\ln (\#$ of pages $)$ & $-1.1705^{*}$ & 0.6151 & $-2.8032^{*}$ & 1.6222 & -0.0872 & 0.7703 \\
\hline $\ln (\# \text { of pages })^{2}$ & $0.1148^{*}$ & 0.0659 & $0.3883^{* *}$ & 0.1729 & 0.0086 & 0.0824 \\
\hline Website & $0.0843^{* * *}$ & 0.0334 & $-0.2309^{* * *}$ & 0.0895 & $0.1668^{* * *}$ & 0.0420 \\
\hline 1990 & -0.5826 & 0.5675 & 0.8897 & 1.5214 & 1.0798 & 0.7139 \\
\hline 1991 & -0.4668 & 0.6280 & 1.4276 & 1.6699 & 1.2528 & 0.7865 \\
\hline 1992 & -0.5649 & 0.5905 & 1.2508 & 1.5834 & 1.1000 & 0.7430 \\
\hline 1993 & -0.5056 & 0.4907 & 0.9029 & 1.3081 & 0.8545 & 0.6153 \\
\hline 1994 & -0.3419 & 0.3614 & 0.5626 & 0.9590 & 0.5944 & 0.4520 \\
\hline 1995 & -0.2494 & 0.4379 & 1.3435 & 1.1431 & $0.9400^{*}$ & 0.5430 \\
\hline 1996 & -0.2663 & 0.4059 & 1.2653 & 1.0627 & $0.8747^{*}$ & 0.5041 \\
\hline 1997 & -0.4296 & 0.3695 & 0.8328 & 0.9868 & 0.6643 & 0.4638 \\
\hline 1998 & -0.3496 & 0.2528 & 0.4699 & 0.6657 & 0.3999 & 0.3148 \\
\hline 1999 & 0.1372 & 0.1191 & 0.2020 & 0.2273 & 0.1831 & 0.1275 \\
\hline $\ln (\#$ of titles $)$ & 0.1349 & 0.1229 & $-1.6758^{* * *}$ & 0.3056 & 0.1054 & 0.1507 \\
\hline $\ln (\# \text { of titles })^{2}$ & -0.0278 & 0.0236 & $0.2958^{* * *}$ & 0.0617 & -0.0474 & 0.0294 \\
\hline Share in women's mag. & -0.0548 & 0.1349 & $-0.8209^{* *}$ & 0.3464 & -0.2161 & 0.1673 \\
\hline Average age & 0.0783 & 0.1096 & 0.3116 & 0.2066 & 0.1708 & 0.1167 \\
\hline Average entry order & -0.5289 & 0.3856 & 1.2395 & 1.0348 & 0.7503 & 0.4854 \\
\hline Average \# of pages & -0.0006 & 0.0008 & $0.0058^{* * *}$ & 0.0018 & 0.0009 & 0.0009 \\
\hline Entryorder & -0.1139 & 0.0906 & 0.1211 & 0.1340 & $-0.1721^{* *}$ & 0.0879 \\
\hline Entryorde $e^{2} r$ & 0.0052 & 0.0047 & -0.0079 & 0.0067 & 0.0058 & 0.0045 \\
\hline Average market reach & 0.0286 & 0.0275 & 0.0002 & 0.0450 & $0.0669^{* * *}$ & 0.0217 \\
\hline Constant & -0.3041 & 5.3583 & -9.1290 & 12.5054 & $-11.9368^{* * *}$ & 6.2721 \\
\hline \multicolumn{7}{|c|}{ Tests for joint significance } \\
\hline Quality characteristics & 59.42 & 0.0000 & 101.16 & 0.0000 & 40.53 & 0.0000 \\
\hline Entire instruments & 11.26 & 0.2582 & 56.17 & 0.0000 & 51.08 & 0.0000 \\
\hline Price-instruments & 7.73 & 0.2585 & 47.52 & 0.0000 & 13.01 & 0.0429 \\
\hline $\ln (\#$ of titles $)$ & 1.43 & 0.4899 & 30.08 & 0.0000 & 4.32 & 0.1155 \\
\hline$\hat{\ln }\left(s_{j \mid g}\right)$ instruments & 4.26 & 0.2348 & 1.64 & 0.6499 & 15.49 & 0.0014 \\
\hline Order & 1.65 & 0.4379 & 1.64 & 0.4401 & 6.61 & 0.0368 \\
\hline Specification & 387.92 & 0.0000 & 320.48 & 0.0000 & 227.83 & 0.0000 \\
\hline \multicolumn{7}{|c|}{ Random vs. fixed effects specification issues and $\rho$-estimate } \\
\hline Random vs. fixed effects & 25.57 & 0.1805 & 8.25 & 0.9901 & 20.66 & 0.4173 \\
\hline LR-test random effects & 1398.43 & 0.0000 & 790.43 & 0.0000 & 1306.01 & 0.0000 \\
\hline \multicolumn{7}{|c|}{ Within, between and overall $R^{2}$} \\
\hline Within & 0.5528 & & 0.3907 & & 0.3964 & \\
\hline Between & 0.2271 & & 0.7637 & & 0.4201 & \\
\hline Overall & 0.2514 & & 0.7481 & & 0.4353 & \\
\hline \multicolumn{7}{|c|}{ \# of obs. and \# of groups } \\
\hline \# of obs. & 368 & & 368 & & 368 & \\
\hline \# of groups & 41 & & 41 & & 41 & \\
\hline
\end{tabular}




\section{References}

Agarwal, R. and M. Gort (1996). The Evolution of Markets and Entry, Exit and the Survival of Firms. Review of Economics and Statistics, 69, 567-574.

Anderson, S.P., A. de Palma and J.-F. Thisse (1992). Discrete Choice Theory of Product Differentiation. The MIT Press, Cambridge, Massachusetts.

Baltagi, B.H. (1995). Econometric Analysis of Panel Data. Wiley, New York.

Baltagi, B.H. and P.X. Wu (1999). Unequally spaced panel data regressions with $\operatorname{AR}(1)$ disturbances. Econometric Theory 15, 814-823.

Berry, S. (1994). Estimating Discrete-choice Models of Product Differentiation. The RAND Journal of Economics 25(2), 242-262.

Berry, S., J. Levinsohn and A. Pakes (1995). Automobile prices in market equilibrium. Econometrica 63, 841-890. 481.

Berry, S., J. Levinsohn and A. Pakes (1997). Differentiated products demand systems from a combination of micro and macro data: The new car market. NBER working paper 6481.

Berry, S. and Ariel Pakes (1999). Estimating the pure hedonic discrete choice model. (downloadable from the internet at:

http://post.economics.harvard.edu/faculty/pakes/papers/mslides.ps).

Davis, P. (1998). Spatial competition in retail markets: movie theaters. MIT Sloan School of Business mimeo.

Davis, P. (2000). Empirical models of demand for differentiated products. European Economic Review 44, 993-1005.

Gruner + Jahr (2001). Market- und Medienentwicklung 1990-2001. Gruner + Jahr, Hamburg.

Hausman, J.A. (1978). Specification test in econometrics. Econometrica 46, $1251-1271$.

Jahreszeitenverlag (2001). Funktions-Analyse: Factbook für Inhalte und Portraits von Zeitschriften, Hamburg. internet download at:

http://media.spiegel.de/fa_frame.html.

Moral, M. and J. Jaumandreu (1998). Automobile Demand. Model Cycle and Price Effects, DT 9806, PIE-FEP, Madrid; forthcoming in Journal of Industrial Economics. 
Nevo, A. (2000a). Mergers with Differentiated Products: The Case of the Ready-to-Eat Cereal Industry, The RAND Journal of Economics, 31(3), $395-421$.

Nevo, A. (2000b). A Practitioner's Guide to Estimation of Random Coefficients Logit Models of Demand, Journal of Economics \& Management Strategy, $9(4), 513-548$.

Nevo, A. (2001). Measuring Market Power in the Ready-to-Eat Cereal Industry, Econometrica, 69(2), 307-342.

Petrin, A. (1998). Quantifying the benefits of new products: The case of the minivan. University of Chicago mimeo.

Statistisches Bundesamt (1990-1999). Statistisches Jahrbuch fr die Bundesrepublik Deutschland und das Ausland. Schäffer-Poeschel, Stuttgart.

Trajtenberg, M. (1989). The Welfare Analysis of Product Innovations, with an Application to Computed Tomography Scanners. Journal of Political Economy 97(21), 444-479.

Verboven, F. (1996). International Price Discrimination in the European Car Market. RAND Journal of Economics 27(2), 240-268.

Wojcik, C. (2000). Alternative Models of Demand for Automobiles. Economics Letters 68, 113-118. 